\section{Growth and Survival of Pinctada margaritifera Mother of Pearl Oyster Co- cultured with Kappaphycus alvarezii Seaweeds}

\section{Ram EJ and Morris C}

School of Marine Studies, University of the South Pacific, Suva, Republic of Fiji

*Corresponding author: Ram EJ, School of Marine Studies, University of the South Pacific, Suva, Republic of Fiji, Tel: +6793381044 E-mail: ram_emanuel@yahoo.com Rec Date: June 20, 2018; Acc Date: August 20, 2018; Pub Date: August 24, 2018

Copyright: (C) 2018 Ram EJ, et al. This is an open-access article distributed under the terms of the Creative Commons Attribution License, which permits unrestricted use, distribution, and reproduction in any medium, provided the original author and source are credited.

\begin{abstract}
This study investigated the effect of co-culturing Pinctada margaritifera pearl oysters with Kappaphycus alvarezii on the biomass of fouling organisms on pearl oysters. The experiment also investigated the effect of reduced fouling due to co-culture on the growth rate of Pinctada margaritifera pearl oysters. The experiment had a treatment and control. Both treatment and control had 5 panel nets with 21 oysters. The result indicated that co-cultured oysters had significantly higher growth rates than the monoculture oysters. The results also showed that the co-cultured Pinctada margaritifera oysters had less fouling organisms attached to it when compared to monoculture oysters.
\end{abstract}

Keywords: Pinctada margaritifera; Kappaphycus alvarezii; Mother of Pearl Oysters (MOP); Co-culture; Growth rate

\section{Introduction}

\section{Culture of pearl oyster}

Culturing any single species at any intensity in any water type is known as monoculture [1]. In the Pacific, pearl oysters are often monoculture on structures comprising a strong main line, which is held in place and a float using anchors and buoys respectively [2]. The oysters are placed in; chaplets, pocket panels, lantern baskets or spat collectors, and hang on the main line [2]. This method is preferred as the entire farm structures are in the water column so the farm is sheltered during rough weather. Moreover, the material costs less and if the need arises, lines can be relocated [2].

\section{Culture of seaweeds}

Kappaphycus alvarezii is a micro-algae that comes in colors such as red, brown, yellowish and green [3]. It occurs in reef zones of IndoPacific, China, Japan, Southeast Asia and east Africa regions to Guam [4]. Kappaphycus alvarezii seaweed is of commercial importance for the extraction of carrageenan [5]. Carrageenan, sulfated polysaccharide, is major cell wall component of Kappaphycus alvarezii [6]. Carrageenan is utilized as a; thickener, emulsifier, stabilizer and gelling agent, by the food, pharmaceutical, textile and cosmetics industry [7]. Kappaphycus alvarezii seaweeds are cultured in the ocean using a floating bamboo method, mangrove stakes and net method, and bottom monoline method [8]. In all methods, seaweed seedlings are tied using a string to lines (rope or fishing line) which are stretched in a row and staked at each end [8]. This method of seaweed farming has been recognized to be economical, easy to construct, manage and maintain [8].

\section{Co-culturing}

It has been proven that co-culturing pearl oysters with red algae helps as the presence of algae has positive effects on pearl oyster growth [9] and the quality of produced pearls [10]. The seaweed, Kappaphycus alvarezii is edible seaweed consumed in different forms by people in many countries [11]. Marine algae have the ability to produce chemically active metabolites for protection against other fouling organisms [12]. The active metabolites has antibacterial, antialgal, anti-macro fouling and antifungal properties, which are not only effective in preventing biofouling but have other likely uses, e.g. in therapeutics [12]. Therefore, the overall productivity can be improved by co-culturing oyster with green algae so that the farmers are able to reduce the problem of biofouling.

\section{Research Methodology}

\section{Study site}

The study was conducted using the existing long lines of pearl Pinctada. margaritifera farm known as Valili Pearl Farms in Savusavu Bay, Vanua Levu, Fiji.

\section{Spat collection and selection}

Oyster spats used for this experiment were collected from Savusavu Bay using Accordion-style spat collectors. The spats between $40 \mathrm{~mm}$ and $55 \mathrm{~mm}$ DVM size were selected for this experiment as this was the most abundant size of spats available from the $20 \mathrm{~mm}$ to $70 \mathrm{~mm}$ range.

\section{Collection of seaweed seedlings}

The seaweed seedlings were obtained from the Yaroi youth seaweed farm. The seaweed farm is also located in Savusavu bay. The seaweed was harvested, packed and transported to the study site in a fiber boat. Approximately 100-gram (initial weight) seaweed seedlings were selected from the harvested seaweeds.

\section{Panel net and experiment setup}

After 21 spats were chosen, they were cleaned using a hand brush and placed into pocket panel nets. There was 1 treatment with 5 replicates including a control. Each panel net had a total of 105 spats. For the treatment, 8 seedlings of $100 \mathrm{~g}$ Kappaphycus alvarezzi seaweed 
were tied onto the panel nets with the spats. The control did not have any seaweed tied onto panel nets with spats. The panel nets were placed on the long line adjacent to each other in the sea.

\section{Taking dry weight of fouling organisms}

After 6 months of culture, fouling organisms were removed from 10 random oysters from each replicate. The fouling organisms were packed into zip lock plastic bags and brought to laboratory where they were dried for 24 hours at $50^{\circ} \mathrm{C}$ in ovens. The dried samples were weighed to 4 decimal points in an analytical balance in milligrams.

\section{Growth measurements and water parameters}

Dorso-ventral measurement (DVM) also referred to as dorsoventral height $(\mathrm{DVH})$ was used for the measurement of growth of pearl oysters [13]. The water parameters were measured using YSI 6920 data logger. YSI 6920 was programmed and left suspended at the experiment site where it recorded water parameters. Salinity, depth, temperature and $\mathrm{pH}$ were retrieved from the equipment during sampling.

\section{Recording and analysis}

The raw growth data of a treatment and a control of Pinctada margaritifera were tested for normality using Shapiro-Wilk test [14]. Data that were normally distributed was analyzed using one-way ANOVA to examine the variability in growth of the oysters over time. The entire tests were performed using SPSS version 22 statistical package.

\section{Results}

\section{Growth rate of pearl oysters}

Pinctada margaritifera mother of pearl oyster showed the highest growth (Table 1) when co-cultured with Kappaphycus alvarezii in Savusavu Bay. The monocultured oysters showed slightly lower growth than the co-cultured oysters.

\begin{tabular}{|l|l|}
\hline Frequency of cleaning & DVM $(\mathrm{mm})$ \\
\hline Monocultured & $9.85 \pm 0.5$ \\
\hline Co-cultured & $10.71 \pm 0.5$ \\
\hline
\end{tabular}

Table 1: Final means ( \pm S.E.) dorso-ventral measurement (DVM) for Pinctada margaritifera for co-cultured treatment and monocultured control from January 2012 through to June 2012.

\section{Growth rate of pearl oysters within co-cultured treatment}

There was a difference in average growth of oysters within the cocultured treatment. The oysters from panel net 2 and 3 had the highest growth. There was a slow growth of oysters in panel 4 and 5. Oysters from panel net 1 showed the lowest growth (Figure 1).

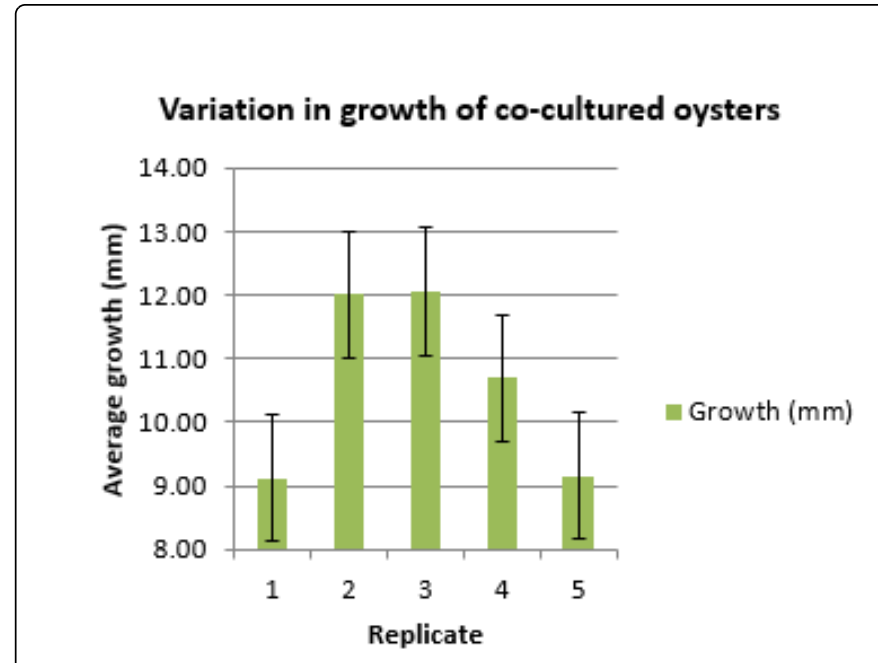

Figure 1: Average growth of Pinctada margaritifera oysters cocultured with Kappaphycus alvarezii.

\section{Growth rate of pearl oysters within monocultured treatment}

There was a difference in average growth of oysters within the monocultured treatment. The oysters from panel net 1 and 5 had the highest growth. There was a slow growth of oysters in Panels 2 and 4 . Oysters from panel net 3 showed the lowest growth (Figure 2).

\section{Variation in gowth moncultured oysters}

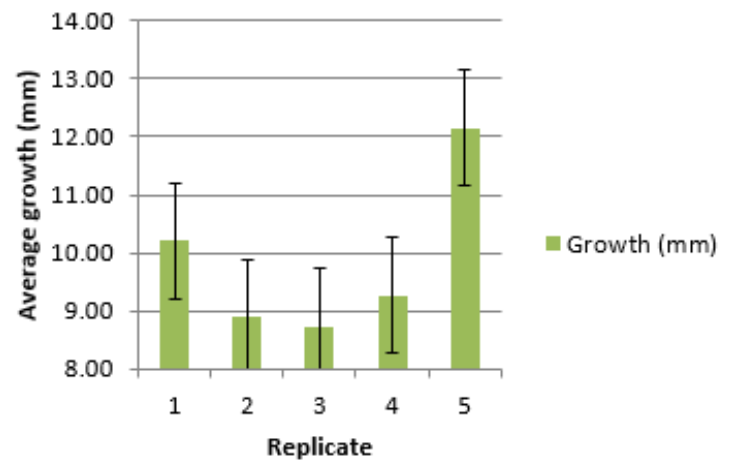

Figure 2: Average growth of Pinctada margaritifera oysters monocultured in Savusavu Bay from January 2012 through to June 2012.

\section{Dry weight of fouling organisms}

There was vast difference in the dry weight of fouling organisms between the monocultured pearl oysters and co-cultured pearl oysters. Dry weight of fouling organisms was lower in oysters that were cocultured. All 5 replicates showed lower dry weight in co-cultured when compared with monocultured oysters (Figure 3). 


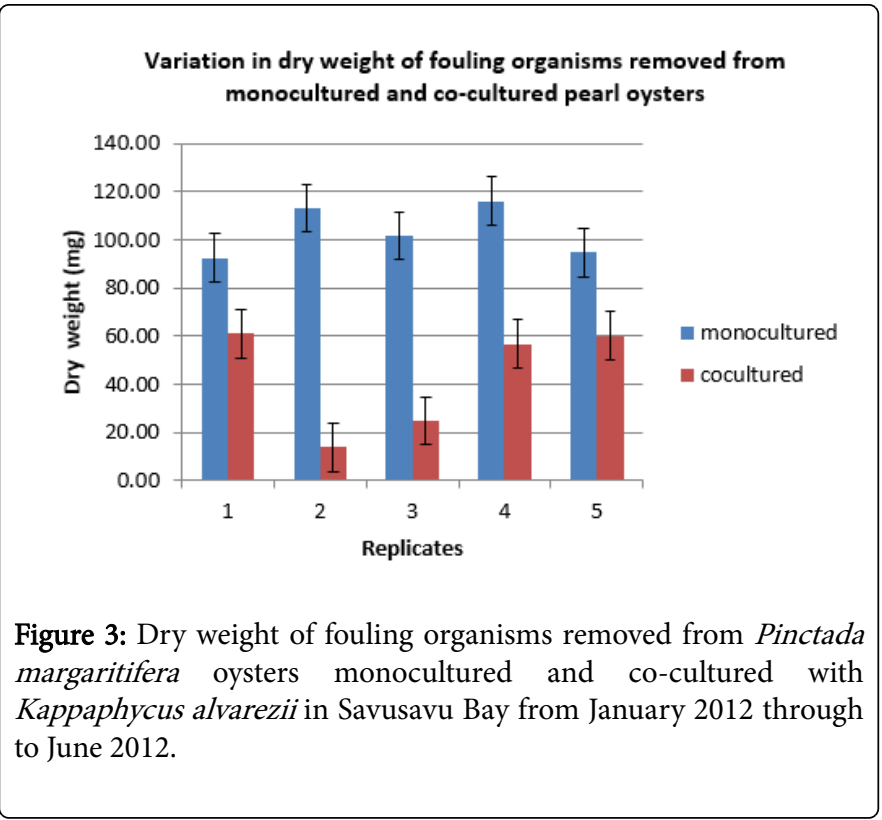

\section{Water parameters}

The water parameters were retrieved from YSI 6920 which measured depth, $\mathrm{pH}$, salinity, temperature from January 2012 through to June 2012 at frequency of every hour.

\section{Statistical analysis}

The normality test showed that the growth data for monocultured and co-cultured Pinctada margaritifera were normally distributed hence a parametric test was run. One way ANOVA test for the Pinctada margaritifera mean growth revealed that there were significant differences between the monocultured and co-cultured oysters, $\mathrm{F}(1,207)=5.987, \mathrm{p}=0.015^{\prime \prime}$ in Savusavu bay between the months of January, 2012 and June, 2012.

\section{Discussion}

Co-culturing Pinctada margaritifera MOP oysters with Kappaphycus alvarezii seaweed had positive effects on the growth rate of oysters. Results showed that the co-cultured oysters had significantly higher growth while the monocultured oysters had lower growth. In China, Pinctada martensi was co-cultured with Kappaphycus alvarezii [9], and similar results were obtained where the oyster had better growth when co-cultured compared to monocultured oysters. The integration of seaweed with animal culture has been previously tested in Taiwan and China [9]. The co-culture system was based on the concept that algae takes up carbon dioxide and uses up metabolic waste from surrounding water releasing oxygen thus creating a favorable environment for animal growth [15]. A study by Wei (1990) showed that the integration of seaweed with animals favored higher growth for animals such as shrimp, mussel and crabs.

The present study showed that the presence of algae in co-culture system had reduced biofouling on Pinctada margaritifera MOP oysters when compared to the monoculture system. Figure 4 showed that all replicates in the co-culture treatment had lower fouling biomass than the monoculture treatment.

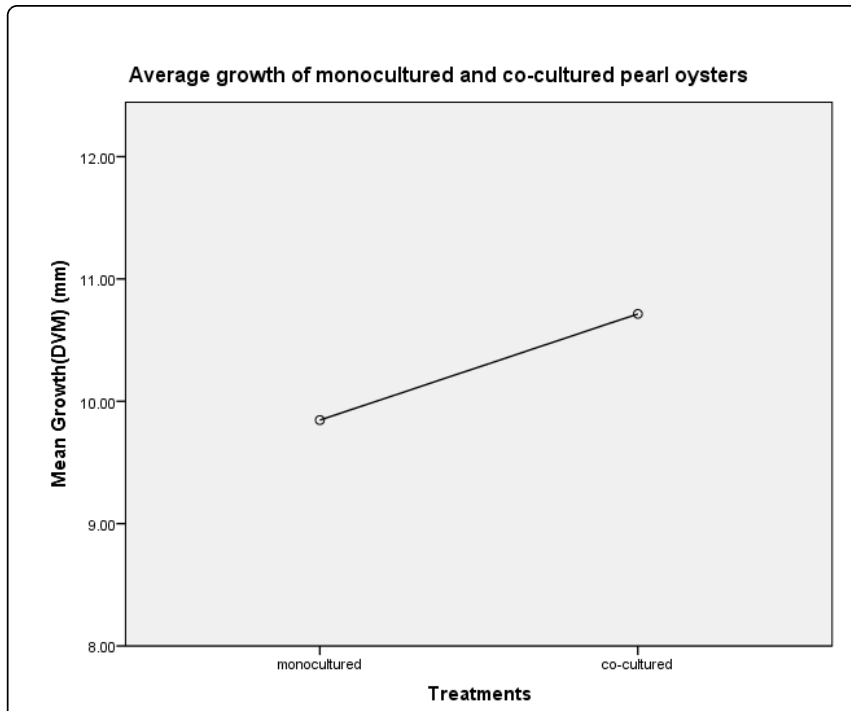

Figure 4: Average growth of Pinctada margaritifera monocultured and co-cultured with Kappaphycus alvarezii in Savusavu Bay from January 2012 through to June 2012.

A reduction in fouling was observed and this may have enhanced Pinctada margaritifera growth in the co-culture system. Over the period of 6 months the mean growth (DVM) of the monocultured oysters was $9.85 \pm 0.5 \mathrm{~mm}$ when compared to co-cultured oysters with significantly higher mean growth (DVM) of $10.71 \pm 0.5 \mathrm{~mm}$. The results showed that the co-culture system reduced the amount of fouling organisms settling on the oyster which positively affected the growth. The common biofouling organisms that were observed were barnacles, other oyster species, Crassostrea species, ascidian species and polychaete worms.

Marine algae release chemically active metabolites in their surrounding waters as protective measure against settling organisms [12]. Active metabolites or biogenic compounds such as halogenated furanones or fimbrolides have anti-bacterial, anti-algal, antimacrofouling and antifungal properties [10]. Co-culturing pearl oysters with seaweeds improves quality of pearls and the pearl retention rate. Oysters co-cultured with red algae produced premium quality pearl when compared with monocultured oysters [10].

\begin{tabular}{|l|l|l|l|l|}
\hline $\begin{array}{l}\text { Water } \\
\text { parameters }\end{array}$ & Minimum & Maximum & Mean & $\begin{array}{l}\text { Standard } \\
\text { deviation }\end{array}$ \\
\hline Depth & 4.06 & 6.45 & 5.66 & 0.68825 \\
\hline $\mathrm{pH}$ & 6.67 & 8.18 & 7.59 & 0.54586 \\
\hline Salinity & 29.2 & 35.16 & 33.73 & 1.77011 \\
\hline Temperature & 25.75 & 29.58 & 28.04 & 1.35339 \\
\hline
\end{tabular}

Table 2: Average water quality parameters (Depth, $\mathrm{pH}$, salinity, and temperature) retrieved from the YSI 6920 data logger placed at the experiment site in Savusavu Bay, Fiji.

In this study, the major water parameters salinity and temperature results (Table 2) indicated that the environmental conditions in which 
Citation: Ram EJ, Morris C (2018) Growth and Survival of Pinctada margaritifera Mother of Pearl Oyster Co-cultured with Kappaphycus alvarezii Seaweeds. J Aquac Res Development 9: 546. doi:10.4172/2155-9546.1000546

Page 4 of 4

Pinctada margaritifera oysters were cultured were near to optimum ranges. Temperature ranged from $25.8-29.6^{\circ} \mathrm{C}$ and salinity ranged from 29.2-35.1 ppt although the maximum salinity went beyond that of the optimum. Optimum functioning temperature for Pinctada margaritifera species is $26-29^{\circ} \mathrm{C}[16,17]$. Although marine oysters can tolerate wide salinity ranges from $40-50 \mathrm{ppt}$, the optimum salinity range is $28-30$ ppt [18].

\section{Conclusion}

Under the environment conditions experienced during the current study and the same degree of handling, Pinctada margaritifera MOP oysters had a significant difference in growth when they were subjected to monoculture and co-culture systems. This study showed that for the best survival and growth, Pinctada margaritifera MOP oysters can be co-cultured with Kappaphycus alvarezii. Co-culture reduces fouling and has the potential to enhance growth of Pinctada margaritifera MOP oysters.

\section{References}

1. Jhingran VG (1987) Introduction to aquaculture: Based on lectures presented by V.G. Jhingran at ARAC (African Regional Aquaculture Centre) for the senior aqua culturists course. Port Harcourt (Nigeria): p: 40.

2. Haws M (2002) The basics of pearl farming: A layman's manual center for tropical and subtropical aquaculture. CTSA Publication No. 127.

3. Areces AJ (1995) Cultivo comercial de carragenofitas del genero Kappaphycus Doty. In Alveal, Ferrario K, Oliveira EC, and Sar E. (Eds) Manual de Métodos Ficológicos. Universidad de Concepción, Concepcion: pp: 529-549.

4. Doty MS, Fisher JR (1987) Experimental culture of seaweeds (Grcrciluria sp.) in Penang, Malaysia. FAO Bay of Bengal Programme BOB (Development of Small-Scale Fisheries GCP/RAS/04O/SWE), Rome. p: 37.

5. Schmidt ÉC, Nunes B, Maraschin M, Bouzon ZL (2010) Effect of ultraviolet- $B$ radiation on growth, photosynthetic pigments, and cell biology of Kappaphycus alvarezii (Rhodophyta, Gigartinales) macroalgae brown strain. Photosynthetica 48: 161-172.

6. Khambhaty Y, Kalpana M, Mahesh G, Sreekumaran T, Pratyush M, et al. (2011) Kappaphycus alvarezii as a source of bioethanol. Bioresource technology 103: 180-185.

7. Paula EJ, Pereira RTL (1998) Da "marinomia" a maricultura da alga exótica, Kappaphycus alvarezii (Doty) Doty ex. Silva (Rhodophyta), para a produção de carragenanas no Brasil. Panor.

8. Juanich GL (1988) Manual on seaweed farming: 1. Eucheumd spp. Manila: ASEAN/UNDP/FAO Regional Small-Scale Coastal Fisheries Development Project.

9. Qian PY, Wu CY, Wu M, Xie YK (1996) Integrated cultivation of the red alga Kappaphycus alvarezii and the pearl oyster Pinctada martensi. Aquaculture 147: 21-35.

10. Wu M, Mak SKK, Zhang X, Qian P (2003) The effect of co-cultivation on the pearl yield of Pinctada martensi (Dumker). Aquaculture 221: 347-356.

11. Dhargalkar VK, Verlecar XN (2009) Southern ocean seaweeds: A resource for exploration in food and drugs. Aquaculture 287: 229-242.

12. Bhadury P, Wright PC (2004) Exploitation of marine algae: Biogenic compounds for potential anti-fouling applications. Planta 219: 561-578.

13. http://pubs.iclarm.net/libinfo/Pdf/Pub\%20SR76\%2021.pdf

14. Shapiro SS, Wilk MB (1965) An analysis of variance test for normality. Biometrica 52: 591-. 10.

15. Shan QX, Wang LC (1985) Study of the mixed culture of algae and prawn. Mar Sci 9: 32-35.

16. Wei SQ (1990) Study of mixed culture of Gracilariatenuistipitata, Penaeuspenicillatus, and Scylla Acta Oceanol Sin 12: 388-394.

17. Doroudi MS, Southgate PC, Mayer RJ (1999) The combined effects of temperature and salinity on embryos and larvae of the blacklip pearl oyster, Pinctada margaritifera. Aquacult Res 30: 271-277.

18. Al-Sayed H, El-Din AKG, Salesh KM (1997) Shell morphometric and some biochemical aspects of the pearl oyster Pinctada radiata (Leach, 1814) in relation to different salinity levels around Bahrain. Arab Gulf J Sci Res 15: 767-782. 